\title{
Qualitative systematic reviews to increase the volume and diversity of patient perspectives included in the development of core outcome sets. Tuberculosis: a pilot study
}

\author{
Lucy Elizabeth Hoppe ${ }^{1,2}$
}

From The 4th Meeting of the Core Outcome Measures in Effectiveness Trials (COMET) Initiative

Rome, Italy. 19-20 November 2014

\section{Background}

Patient involvement is a core value of contemporary healthcare, and an emerging component of core outcome set (COS) methodology.

This project pilots the use of qualitative systematic reviews of patient perspectives on outcome prioritisation in COS development, specifically for a COS for tuberculosis. The fight against tuberculosis has been hampered by the burden of treatment regimens and drug resistance, and clinical trials are ongoing. A COS for tuberculosis will ensure that outcome selection across trials is consistent, free from selection bias and relevant to patients, clinicians and policy-makers.

\section{Methods}

MEDLINE, EMBASE and ASSIA were searched for studies exploring patient perspectives on tuberculosis outcomes and their value. Each search strategy included terms for 1) qualitative research and 2) tuberculosis.

Inclusion criteria: participants of any age with a diagnosis of tuberculosis; direct contact or observation; any geographical location; publication after 2003 and in English.

Studies were appraised using the CASP checklist. Methods for synthesis should be based on the aims of review. Here, the aim is not model or theory generation, but an aggregation of perspectives and experiences. Thematic analysis was therefore used.

\footnotetext{
Correspondence: lucy.hoppe@nice.org.uk

${ }^{1}$ School of Dentistry (Cochrane Oral Health Group), University of Manchester, Manchester, UK

Full list of author information is available at the end of the article
}

\section{Findings}

13 papers were identified [1-13].

Searching for studies was demanding due to inadequate qualitative indexing, non-meaningful titles and poor abstracts. Data extraction was also complex, with substantial irrelevant data.

The included studies were conducted in countries across South America, Africa and Asia. This improved the international relevance of the findings, though perspectives from Europe and North America, as well as more socioeconomically developed areas, was lacking. Participants ranged in age from 5 to 80 , and included an approximately equal number of men and women. There was limited coverage of individuals who had defaulted or failed treatment.

Many participants used indigenous knowledge in place of biomedical knowledge, leading to difficulties in interpretation.

Outcomes that impair physical and social functioning are emphasised, with their importance often linked to fear or stigma. Mortality and treatment success or failure, as well as the adverse effects of treatment, were noted. Despite this, they are not consistently reported in previous clinical trials. For example, a Cochrane Review [14] into the use of rifabutin for active tuberculosis found that only 2 of 8 RCTs reported cure and 4 of 8 reported adverse events.

No studies were designed with outcome prioritisation in mind. The evidence was largely 'indirect' and 'concealed' in the results, reflecting the lack of conceptualisation of the phenomenon (patient outcome prioritisation) and novelty of the research area. The paucity of direct information that explicitly explores patient perspectives 
on the prioritisation of treatment outcomes is justification for future qualitative research.

\section{Acknowledgements}

Funding was provided by the Cochrane Oral Health Group.

\section{Authors' details}

${ }^{1}$ School of Dentistry (Cochrane Oral Health Group), University of Manchester, Manchester, UK. ${ }^{2}$ Centre for Clinical Practice, National Institute for Health and Care Excellence, London, UK

Published: 29 May 2015

\section{References}

1. Reyes-Guillen I, Sanchez-Perez HJ, Cruz-Burguete J, Izaurieta-de Juan M: Anti-tuberculosis treatment defaulting: an analysis of perceptions and interactions in Chiapas, Mexico. Salud Publica de Mexico 2008, 50(3):251-257.

2. Chileshe $M$, Bond VA: Barriers and outcomes: TB patients co-infected with HIV accessing antiretroviral therapy in rural Zambia. AIDS Care 2010, 22(Suppl 1):51-59.

3. Rundi C: Understanding tuberculosis: perspectives and experiences of the people of Sabah, East Malaysia. Journal of Health, Population and Nutrition 2010, 28(2):114-123.

4. van den Boogaard J, Msoka E, Homfray M, Kibiki GS, Heldens JJHM, et al: An exploration of patient perceptions of adherence to tuberculosis treatment in Tanzania. Qualitative Health Research 2012, 22(6):835-845.

5. Acha J, Sweetland A, Guerra D, Chalco K, Castillo H, et al: Psychosocial support groups for patients with multidrug-resistant tuberculosis: five years of experience. Global Public Health 2007, 2(4):404-417.

6. Franck C, Seddon JA, Hesseling AC, Schaaf HS, Skinner D, Reynolds L: Assessing the impact of multidrug-resistant tuberculosis in children: an exploratory qualitative study. BMC Infectious Diseases 2014, 14:426.

7. Paz-Soldan VA, Alban RE, Jones CD, Oberhelman RA: The provision of and need for social support among adult and pediatric patients with tuberculosis in Lima, Peru: a qualitative study. BMC Health Services Research 2013, 13:290.

8. Dias AA, de Oliveira DM, Turato ER, de Figueiredo RM: Life experiences of patients who have completed tuberculosis treatment: a qualitative investigation in southeast Brazil. BMC Public Health 2013, 13:595.

9. Tadesse T, Demissie M, Berhane $Y$, Kebede $Y$, Abebe M: Long distance travelling and financial burdens discourage tuberculosis DOTs treatment initiation and compliance in Ethiopia: a qualitative study. BMC Public Health 2013, 13:424.

10. Gebremariam MK, Bjune GA, Frich JC: Barriers and facilitators of adherence to TB treatment in patients on concomitant TB and HIV treatment: a qualitative study. BMC Public Health 2010, 10:651.

11. Zhang SR, Yan H, Zhang JJ, Zhang TH, Li XH, Zhang YP: The experience of college students with pulmonary tuberculosis in Shaanxi, China: a qualitative study. BMC Infectious Diseases 2010, 10:174.

12. Paz EP, Sa AM: The daily routine of patients in tuberculosis treatment in basic health care units: a phenomenological approach. Revista LatinoAmericana de Enfermagem 2009, 17(2):180-186.

13. Sagbakken M, Frich JC, Bjune G: Barriers and enablers in the management of tuberculosis treatment in Addis Ababa, Ethiopia: a qualitative study. BMC Public Health 2008, 8:11.

14. Davies GR, Cerri S, Richeldi L: Rifabutin for treating pulmonary tuberculosis. Cochrane Database of Systematic Reviews 2007, 4, article no. CD005159.

doi:10.1186/1745-6215-16-S1-O3

Cite this article as: Hoppe: Qualitative systematic reviews to increase the volume and diversity of patient perspectives included in the development of core outcome sets. Tuberculosis: a pilot study. Trials 2015 16(Suppl 1):03

\section{Submit your next manuscript to BioMed Central and take full advantage of:}

- Convenient online submission

- Thorough peer review

- No space constraints or color figure charges

- Immediate publication on acceptance

- Inclusion in PubMed, CAS, Scopus and Google Scholar

- Research which is freely available for redistribution

Submit your manuscript at www.biomedcentral.com/submit 